\title{
ACCEPTANCE OF OTT VIDEO STREAMING PLATFORMS IN INDIA DURING COVID -19: EXTENDING UTAUT2 WITH CONTENT AVAILABILITY
}

\author{
Dr. Sonali Malewar \\ Assistant Professor, \\ Amity University Chhattisgarh, Raipur \\ Dr. Shweta Bajaj \\ Assistant Professor, \\ AAFT University of Media and Arts, Raipur (C.G.)
}

\begin{abstract}
The paper aims at identifying factors that stimulates the customers to adopt and use OTT video streaming platforms in India by applying unified theory of acceptance and use of technology 2 (UTAUT2) model. The study has also attempted to check the moderation effect of age, gender, experience. The study uses a questionnaire to gather the primary data of 277 users of OTT video streaming platforms of India as respondents. The data was examined using SmartPLS 3.3.2 software. The key drivers of adopting and using OTT video streaming platforms are performance expectancy, price value, habit and content availability. The study approves the relevance of UTAUT2 model in the present context. The study also explains the moderating effect of gender, experience and age in UTAUT2 model constructs with respect to OTT video streaming platforms. The market of OTT platforms in India is growing tremendously and is projected to gain the momentum in coming years. Thus, it is imperious to comprehend the behavioral intention of consumers. The outcomes of the study will help the managers in comprehending and devising different strategies for consumers of OTT video streaming platforms. The study is first ever attempt to the best understanding of research to observe the acceptance of OTT video streaming apps using UTAUT2 model.
\end{abstract}

Keywords: OTT Video Streaming, Adoption, UTAUT2, Behavioral Intention

\section{INTRODUCTION}

The upsurge practice of internet and telecommunication devices have changed the institutional thinking of media consumers. The growing urge of consumer to emphasis more on adapted content have gave birth to the new platforms like Over the top (OTT). With the rise of smart devices and technology with internet network and the digitization of video content, clientele can appreciate an assortment of video content without any barriers (Shin et al., 2016). The rise of administration stages that gives video content via open internet has prompted a change in outlook, from the conventional telecom industry. Gonçalves et al., (2014) characterized OTT as "video conveyance utilizing the Internet Protocol over an open system". An OTT platform is an online video supplier that conveys video substance to customers dependent on the Internet (Erman et al., 2011; Sujata et al., 2015). It was with YouTube, a free of charge videosharing website set up in 2005 and taken over by Google in 2006, that OTT video services started to get well known with the community. After that many OTT video streaming platforms such as Netflix, Amazon prime, Alt Balaji, Zee5, Hotstar, Voot and many more came into existence and are apprehending the media consumer market (Singh, 2019). This is an example that shoppers' substance utilization is evolving altogether. Buyers can access and enjoy content whenever they wish, anyplace or anytime on their Smartphone. Specifically, video content utilization is taking off (Ulin, 2013; Bentley et al., 2019), as it adored as a substance reasonable for current life designs; the video content is short and altered or quick utilization in restricted period and spot.

The rise of OTT platforms in India is also driven by the huge support from the telecommunication industry. The internet packages offered today are very affordable, compared to previous times (Mairaru et al., 2019). Times are gone when data used to cost a hefty amount, with a substantial increase in the daily data limit, after the entry of Reliance Jio to the telecom market (Joy and Bahl, 2018). 
Another factor that contributed significantly to the recently accomplished popularity of OTT video streaming platforms, is the lack of substitute entertainment media option in recent times of pandemic. The imposition of nation-wide lockdown to contain the spread of COVID - 19 has taken its huge toll on media industry in India. Shutting down of production houses and cinema hall across the nation created huge demand of OTT video streaming platforms across the country, for original series and movies (Shaikh and Aggarwal, 2020). An article published in Business standard 2020, suggests that, this is leading to the development of habit of growing usage of OTT video streaming platforms as new normal.

As per the report published in Economic Times April 2020, the OTT video streaming platforms in India have seen a growth of 34 percent in March 2020. As per the industry experts, the recent increase in viewership on OTT video streaming platforms have already propelled their growth of next 5 years. It has been forecasted that the OTT platforms revenue could touch US\$ 4 Billion by year 2025 (www.ibef.org). Even the prominent players of the media industry have started investing in the OTT video streaming platforms startups (IBEF, 2020). The popularity and acceptance of the OTT platforms in India can be accessed by the fact that, mainstream Bollywood movies are also being released in these platforms, mentions report of Business standard, April 2020. With the growing demand of these platforms, it is important to understand what behavioral factors are leading to this growth. Proper thoughtful knowledge of these factors would help the marketers understand the behavior of the consumers of OTT video streaming Platforms.

The extant of literature available of OTT platforms have considered the Consumer adoption behavior through Strategic management (Shin et al.,2016), while some have compared the traditional television with OTT platforms on its performance (Chen, 2019; Li, 2017). Ogidiaka and Ogwueleka, (2019), have explored the consumer behavior of OTT platforms. However, a gap still exists as the studies conducted till date have not yet taken into consideration consumer's intention to use OTT and what leads to actual use of
OTT video streaming platforms. Thus, in the present study the researcher aims at developing an understanding of factors that leads to acceptance, and usage of OTT video streaming platforms, by the consumers. To comprehend the same, the research employs Unified theory of acceptance and use of technology 2 (UTAUT2) given by Venkatesh $e t$ al., (2012) and have extended the base model with content availability.

To meet the objective of the research, the paper is categorized into five sections. The first section of the paper comprises of the introduction to the OTT video streaming platforms and the purpose of the research. The second sections contain the review of the work done in the past and the introduction to UTAUT2 model. The third section comprises of the research methodology used for the present research. The fourth sections comprise of the data analysis and findings, and last section of the paper covers the discussion and implications. The paper ends with concluding remark along with limitation of the present study and scope for the future research.

\section{LITERATURE REVIEW AND HYPOTHESIS DEVELOPMENT \\ OTT video streaming platforms in India}

OTT video streaming platforms in India can be described as the "luxury turned necessity". The number of users of OTT video streaming platform are growing day by day, with India being the home to 687.62 million internet users by September 2019 (Annual report TRAI, 2019), marking the second largest in the world. As per the report of PwC India 2019, India's market of entertainment and media is growing quicker globally and is not to drop the impetus soon. Foreseeing the demand of the OTT video streaming platforms, various channels and companies started launching their apps. In India, various major platforms where introduced in year 2015 and 2016, after the launch of YouTube in 2008. Hotstar was launched on February 2015, Netflix January 2016, Jio TV in 2016, Voot in March 2016, Amazon prime in May 2016 and so on (Fitzgerald, 2019). As per the report published by MICA - School of Ideas, on OTT Platform 2019, the major player in the industry find India to be their potential market, where YouTube has 265 million Indian active users every month. The second in the series is Hotstar, that holds $69.4 \%$ of the Indian OTT 
market. Netflix is investing more on the regional content specific to Indian market and also offering the subscription at the cheapest prize for the Indian market. Ms. Jennifer Salke, Head Amazon studio, states that "India has biggest set of originals for Prime video outside US market"

Other than the internet accessibility, the acceptance of these platforms in India have grown tremendously due to the following reasons. Firstly, the existing smartphone devices for the Indian consumer are compatible for online video streaming, as most of the people watch videos in their smartphones (Gevers, 2019). The habits of the consumer are shifting from television and desktop to mobile phones.

Second, the availability of the personalised content in the regional languages is another reason, which is pushing up the usage frequency (Begum, 2018). Third, the use of advertisement-based monetisation model by OTT video streaming platform which help them offer free services (Jirakasem, and Mitomo, 2019). Thus, giving a rise to the popularity and subscribers to OTT video streaming platforms in Indian market (Sundaravel and Elangovan, 2020). Considering this inflation, it is important to understand how comfortable the user, of OTT video streaming platforms, are with the technology innovation than tradition television.

\section{Theoretical Framework}

Venkatesh et al., (2003), proposed the Unified theory of acceptance and use of technology (UTAUT) model where he reported the four constructs social influence, effort expectancy, facilitating conditions and performance expectancy to be the direct determinants of use behaviour and behavioural intention. Venkatesh et al., (2012) extended the UTAUT model with three constructs namely Price value, habit and hedonic motivation, along with the four constructs already present in the model and named it as UTAUT2. In the UTAUT2 model the moderating impact of age, gender and experience has also been assessed. This model has advantage and acceptance over the other technology acceptance model because, firstly, it is designed with the combination of eight prominent theories and models.
Second, it has been accepted by the researchers to identify the relation between intention of using a technology, and actually using a technology (Yuan et al., 2015; Gupta et al., 2017; Kwateng et al., 2019; Shaw and Sergueeva, 2019; Ramírez-Correa et al., 2019; Duarte and Pinho, 2019; Alalwan, 2020). Third, UTAUT2 model had all the important factors incorporated, that will define behavioural intention (BI) in the best manner when it comes to technology actual usage (AU) and acceptance. Some of the studies conducted in the past is mentioned in table no. 1 , where UTAUT2 model has been validated and extended with different constructs for different technologies.

\section{Performance Expectancy (PE)}

Performance expectancy states the stage of trust that clients get in utilizing the structure to develop their activity implementation ((Venkatesh et al., 2012; Moorthy et al., 2019). Performance expectancy in terms of OTT media platforms can be understood as the expediency of time and place they offers to the consumers. The relationship between behavior intentions and performance expectancy has been moderated by the age, gender and experience, where it has been reported by the previous studies that young customers and males are more conscious about the technology (Venkatesh et al., 2003 and Kwateng et al., 2019). Thus, the hypothesis is framed as.

H1: Performance expectancy impacts the BI for adoption of OTT video streaming platforms. H1a: Gender moderates the impact of performance expectancy towards BI

H1b: Age moderates the impact of performance expectancy towards BI.

H1c: Experience moderates the impact of performance expectancy towards BI

\section{Effort Expectancy (EE)}

It is the level of simplicity correlated with purchasers' utilization of technology (Venkatesh et al., 2012; Miltgen, et al., 2013). It is the ease with which consumers can learn and interact with OTT video streaming platforms. Age, gender and experience moderate the relationship between behavioral intention and effort expectancy. The hypothesis is as mentioned: 
H2: Effort expectancy impacts the BI for adoption of OTT video streaming platforms.

H2a: Gender moderates the impact of Effort expectancy towards $B I$.

H2b: Age moderates the impact of Effort expectancy towards $B I$.

H2c: Experience moderates the impact of Effort expectancy towards BI.

\subsubsection{Social Influence (SI)}

It is the level to which buyers see that considerable others (e.g., dear ones) accept they should make use of a specific technology
(Venkatesh et al., 2012; Rogers, 2010; Huang and Kao 2015). Thus, use of OTT platforms by consumers is motivated and appreciated by the social circle around the consumer.

H3: Social Influence impacts the BI for adoption of OTT media platforms.

H3a: Gender moderates the impact of Social Influence towards BI.

H3b: Age moderates the impact of Social Influence towards BI.

H3c: Experience moderates the impact of Social Influence towards BI.

Table No. 1: Application of UTAUT2 model as reported by Literature

\begin{tabular}{|c|c|c|c|c|c|c|}
\hline $\begin{array}{c}\text { Author / } \\
\text { Year }\end{array}$ & Context & $\begin{array}{l}\text { Area of } \\
\text { study }\end{array}$ & $\begin{array}{c}\text { Significant } \\
\text { Construct }\end{array}$ & $\begin{array}{c}\text { Insignificant } \\
\text { Construct }\end{array}$ & $\begin{array}{c}\text { Model } \\
\text { extended with }\end{array}$ & $\begin{array}{c}\text { Significance } \\
\text { of Extended } \\
\text { Construct }\end{array}$ \\
\hline $\begin{array}{l}\text { Yang, } \\
\text { (2013) }\end{array}$ & $\begin{array}{l}\text { M - } \\
\text { Learning }\end{array}$ & China & $\begin{array}{l}\text { Performance } \\
\text { Expectancy, Social } \\
\text { Influence, Price } \\
\text { Value, hedonic } \\
\text { motivation }\end{array}$ & $\begin{array}{l}\text { Effort Expectancy, } \\
\text { Habit of Using } \\
\text { Mobile phones. }\end{array}$ & $\begin{array}{l}\text { Self- } \\
\text { Management } \\
\text { of learning }\end{array}$ & Significant \\
\hline $\begin{array}{l}\text { Yuan et al., } \\
\text { (2015) }\end{array}$ & $\begin{array}{l}\text { Health and } \\
\text { fitness } \\
\text { apps }\end{array}$ & $\begin{array}{l}\text { United } \\
\text { States }\end{array}$ & $\begin{array}{l}\text { Performance } \\
\text { Expectancy, } \\
\text { hedonic } \\
\text { motivation, price } \\
\text { value, habit }\end{array}$ & $\begin{array}{l}\text { Social influence, } \\
\text { effort expectancy, } \\
\text { facilitating } \\
\text { conditions. }\end{array}$ & - & - \\
\hline $\begin{array}{l}\text { Oliveira et } \\
\text { al., (2016) }\end{array}$ & $\begin{array}{l}\text { Mobile } \\
\text { payment }\end{array}$ & Portugal & $\begin{array}{l}\text { Performance } \\
\text { expectancy, Social } \\
\text { influence }\end{array}$ & $\begin{array}{l}\text { Effort expectancy, } \\
\text { facilitating } \\
\text { conditions, } \\
\text { hedonic } \\
\text { motivation, price } \\
\text { value. }\end{array}$ & \begin{tabular}{l|} 
perceived \\
technology \\
securities, \\
compatibility, \\
innovativeness
\end{tabular} & Significant \\
\hline $\begin{array}{l}\text { Gupta et } \\
\text { al., (2017) }\end{array}$ & $\begin{array}{l}\text { Travel } \\
\text { Apps }\end{array}$ & India & $\begin{array}{l}\text { Performance } \\
\text { Expectancy, Social } \\
\text { Influence, Price } \\
\text { saving, Habit }\end{array}$ & $\begin{array}{l}\text { Hedonic } \\
\text { Motivation, } \\
\text { Facilitating } \\
\text { Conditions, Effort } \\
\text { Expectancy. }\end{array}$ & $\begin{array}{l}\text { Perceived } \\
\text { Risk, } \\
\text { Perceived } \\
\text { Trust }\end{array}$ & Significant \\
\hline $\begin{array}{l}\text { Tak and } \\
\text { Panwar, } \\
(2017)\end{array}$ & $\begin{array}{l}\text { Mobile } \\
\text { app-based } \\
\text { shopping }\end{array}$ & India & $\begin{array}{l}\text { Performance } \\
\text { Expectancy, Social } \\
\text { Influence, Price } \\
\text { saving, Habit, } \\
\text { Hedonic } \\
\text { Motivation, } \\
\text { Facilitating } \\
\text { Conditions, Effort } \\
\text { Expectancy }\end{array}$ & - & $\begin{array}{l}\text { Deal } \\
\text { Proneness }\end{array}$ & Significant \\
\hline $\begin{array}{l}\text { Farooq et } \\
\text { al., (2017) }\end{array}$ & $\begin{array}{l}\text { Lecture } \\
\text { Capture } \\
\text { system }\end{array}$ & Malaysia & $\begin{array}{l}\text { Performance } \\
\text { Expectancy, Social } \\
\text { Influence, Price } \\
\text { saving, Habit, } \\
\text { Hedonic } \\
\text { Motivation, } \\
\text { Facilitating } \\
\text { Conditions, Effort } \\
\text { Expectancy. }\end{array}$ & - & $\begin{array}{l}\text { Personal } \\
\text { innovativeness }\end{array}$ & Significant \\
\hline
\end{tabular}




\begin{tabular}{|c|c|c|c|c|c|c|}
\hline $\begin{array}{c}\text { Author / } \\
\text { Year }\end{array}$ & Context & $\begin{array}{l}\text { Area of } \\
\text { study }\end{array}$ & $\begin{array}{l}\text { Significant } \\
\text { Construct }\end{array}$ & $\begin{array}{c}\text { Insignificant } \\
\text { Construct }\end{array}$ & $\begin{array}{c}\text { Model } \\
\text { extended with }\end{array}$ & $\begin{array}{c}\text { Significance } \\
\text { of Extended } \\
\text { Construct }\end{array}$ \\
\hline $\begin{array}{l}\text { Praveena } \\
\text { and } \\
\text { Thomas, } \\
(2018)\end{array}$ & $\begin{array}{l}\text { Social } \\
\text { networking } \\
\text { sites }\end{array}$ & India & $\begin{array}{l}\text { Performance } \\
\text { expectancy, Effort } \\
\text { expectancy, habit, }\end{array}$ & $\begin{array}{l}\text { Social Influence, } \\
\text { facilitating } \\
\text { Conditions, } \\
\text { Hedonic } \\
\text { Motivation }\end{array}$ & $\begin{array}{l}\text { Trust, } \\
\text { Visibility, } \\
\text { Social } \\
\text { connects }\end{array}$ & Significant \\
\hline $\begin{array}{l}\text { Kwateng } \\
\text { et al., } \\
(2019)\end{array}$ & $\begin{array}{l}\text { Mobile } \\
\text { banking }\end{array}$ & Ghana & Habit, price value & $\begin{array}{l}\text { Effort expectancy, } \\
\text { Facilitating } \\
\text { conditions, } \\
\text { Hedonic } \\
\text { motivation, } \\
\text { Performance } \\
\text { expectancy, Social } \\
\text { influence. }\end{array}$ & Trust & Significant \\
\hline $\begin{array}{l}\text { Shaw and } \\
\text { Sergueeva, } \\
(2019)\end{array}$ & $\begin{array}{l}\text { Mobile } \\
\text { commerce }\end{array}$ & Canada & $\begin{array}{l}\text { Hedonic } \\
\text { motivation, } \\
\text { Performance } \\
\text { expectancy }\end{array}$ & $\begin{array}{l}\text { Social Influence, } \\
\text { Facilitating } \\
\text { Conditions, Habit, } \\
\text { Effort expectancy. }\end{array}$ & $\begin{array}{l}\text { perceived } \\
\text { value, } \\
\text { perceived } \\
\text { privacy } \\
\text { concerns }\end{array}$ & Significant \\
\hline $\begin{array}{l}\text { Ramírez- } \\
\text { Correa et } \\
\text { al., (2019) }\end{array}$ & $\begin{array}{l}\text { Online } \\
\text { games in } \\
\text { mobile } \\
\text { devices }\end{array}$ & Spain & $\begin{array}{l}\text { Habit, hedonic } \\
\text { motivation, Social } \\
\text { Influence }\end{array}$ & $\begin{array}{l}\text { Performance } \\
\text { Expectancy, Effort } \\
\text { expectancy, } \\
\text { facilitating } \\
\text { condition, Price } \\
\text { value }\end{array}$ & - & - \\
\hline $\begin{array}{l}\text { Duarte, } \\
\text { and Pinho, } \\
(2019) \text {. }\end{array}$ & $\begin{array}{l}\text { Mobile } \\
\text { health } \\
\text { adoption }\end{array}$ & Portugal & $\begin{array}{l}\text { Facilitating } \\
\text { conditions, habit, } \\
\text { performance } \\
\text { expectancy }\end{array}$ & $\begin{array}{l}\text { Effort expectancy, } \\
\text { price value, } \\
\text { hedonic } \\
\text { motivation and } \\
\text { social influence. }\end{array}$ & - & - \\
\hline $\begin{array}{l}\text { Alalwan, } \\
(2020)\end{array}$ & $\begin{array}{l}\text { Mobile } \\
\text { food } \\
\text { ordering } \\
\text { apps }\end{array}$ & Jordan & $\begin{array}{l}\text { Performance } \\
\text { expectancy, Habit, } \\
\text { Hedonic } \\
\text { Motivation }\end{array}$ & $\begin{array}{l}\text { Facilitating } \\
\text { conditions, Effort } \\
\text { expectancy, Social } \\
\text { Influence, Price } \\
\text { value }\end{array}$ & $\begin{array}{l}\text { Online rating, } \\
\text { online review, } \\
\text { online } \\
\text { tracking, }\end{array}$ & Significant \\
\hline
\end{tabular}

Source: Past literatures on UTAUT2

\section{Facilitating Conditions (FC)}

It refers to clientele view of the assets and bolster accessible to accomplish a behavior (Brown and Venkatesh 2005; Venkatesh et al., 2012; Huang and Kao 2015). Facilitating conditions can be defined as, availability of the technical infrastructure and support for using OTT video streaming platforms

H4: Facilitating condition impacts the BI for adoption of OTT video streaming platforms.

H4a: Facilitating condition impacts the $A U$ of OTT media platforms.

H4b: Gender moderates the impact of facilitating conditions towards BI.

H4c: Age moderates the impact of facilitating conditions towards BI.
H4d: Experience moderates the impact of facilitating conditions towards BI.

\section{Hedonic Motivation (HM)}

The fun or joy consumers receive from utilizing a technology has been defined as hedonic motivation, and it assumes a noteworthy job in deciding technological nod and use (Venkatesh et al., 2012; Magni et al., 2010; Ryan and Deci, 2000). Hedonic motivation can be defined as the joy of fulfilling the entertainment desires by using OTT video streaming platforms.

H5: Hedonic Motivation impacts the BI for adoption of OTT video streaming platforms. 
H5a: Gender moderates the impact of hedonic motivation towards BI.

H5b: Age moderates the impact of hedonic motivation towards BI.

H5c: Experience moderates the impact of hedonic motivation towards BI.

\section{Price Value (PV)}

It is consumers intellectual transaction amid the apparent reward of the applications, and the fiscal expense for utilizing them (Dodds et al., 1991; Venkatesh et al., 2012). Subscription charges for availing the OTT streaming services would be a huge influencer defining the behavioral intention.

H6: Price Value impacts the BI for adoption of OTT video streaming platforms.

H6a: Gender moderates the impact of price value towards BI.

H6b: Age moderates the impact of price value towards BI.

H6c: Experience moderates the impact of price value towards BI.

\section{Habit (H)}

Habit has been characterized as the scale to which individuals will in general perform practices accordingly on account of learning (Limayem et al. 2007; Kim and Malhotra, 2005; Limayem et al., 2007; Aarts et al., 1998). Once habit of using OTT video platforms is developed it will lead to continuous further intention and actual use of the technology.

H7: Habit impacts the BI for adoption of OTT video streaming platforms.

H7a: Habit impacts the actual usage of OTT video streaming platforms.

H7b: Gender moderates the impact of habit towards BI.

H7c: Age moderates the impact of habit towards BI.

H7d: Experience moderates the impact of habit towards BI

H7e: Gender moderates the impact of habit towards AU.

H7f: Age moderates the impact of habit towards AU.

H7g: Experience moderates the impact of habit towards AU.

\section{Content Availability (CA)}

Content availability is the variety of content offered by the service provider in terms of regional language, genre, quantity and quality that is assessible by large number of consumers (Haryoto, 2015). Availability of original content on OTT video streaming platform often influence user intention and to purchase and use a platform (Sundaravel and Elangovan, 2020).

H8: Content availability impacts the BI for adoption of OTT video streaming platforms.

H8a: Content availability impacts the AU of OTT video streaming platforms.

H8b: Gender moderates the impact of content availability towards $B I$.

H8c: Age moderates the impact of content availability towards $B I$.

H8d: Experience moderates the impact of content availability towards BI.

H8e: Gender moderates the impact of content availability towards $A U$.

H8f: Age moderates the impact of content availability towards AU.

H8g: Experience moderates the impact of content availability towards AU.

\section{Behavioural Intention (BI)}

Social therapists have comprehensively investigated the relations to future behavior and behavioral intentions. Behavioral intention suggests to how much a person has planned conscious designs to perform or not perform some predefined future behavior(s) (Huang and Kao, 2015). Behavioral intention alludes to a client's goal to utilize an additional item or service (Venkatesh et al., 2003).

H9: Behavioral intention impacts the actual usage of OTT video streaming platforms.

H9a: Gender moderates the impact of BI towards $A U$.

H9b: Age moderates the impact of BI towards AU.

H9a: Experience moderates the impact of $B I$ towards AU.

The proposed research model for the present study has been shown in figure no. 1

\section{Research Methodology}

The questionnaire was designed to record the responses. The scale and items used in the study were the same as used by Venkastesh at el., (2013) for UTAUT2 model. The dimension of items was done on a 7-point likert scale where, (7) represents strongly agree and (1) represents strongly disagree. The questionnaire was divided into three parts. Section - I contains the demographic profile of the responds such as age, gender and experience. Section - II contains the question 
related to the opinion of the people regarding their thoughts and beliefs about the subject under study (Tabsh, 2012). The third section of the questionnaire deals with the intention to use and actual usage covering their present, future and past usage records.

The target population considered for the study where the active user of OTT video streaming platforms. The respondents of the study belonged to different backgrounds in terms of economic, social and cultural legacy. The population comprised of all the people such as students, businessmen, housewives and service class. The respondent where selected using the non- probability, purposive sampling technique for the present study. The reason for selecting purposive sampling was, it gave the researchers the freedom to select the respondents who had been actively using OTT media platforms and helped in obtaining the precise and consistent results (Denzin and Lincoln, 2005; Kwateng et al., 2019). The data was collected through the questionnaire, using email survey method. The study uses GPower 3.1 software to calculate the appropriate sample size for the present research.

The proposed research model consists of nine predictor variables, an anticipated effect size (f2) of minimum 0.05, with a statistical power of 95 percent. For the current study, the software suggested a sample size of 262 to be adequate (Erdfelder et al., 1996; Faul et al., 2007; Faul et al., 2009). Keeping this in mind, the data was collected from 305 respondents. Total 277 usable data were obtained after removing the incomplete responses. This satisfied the minimum sample size criteria of 262 obtained from GPower 3.1 Software. The data obtained was analysed using Smart PLS 3.3.2 software.

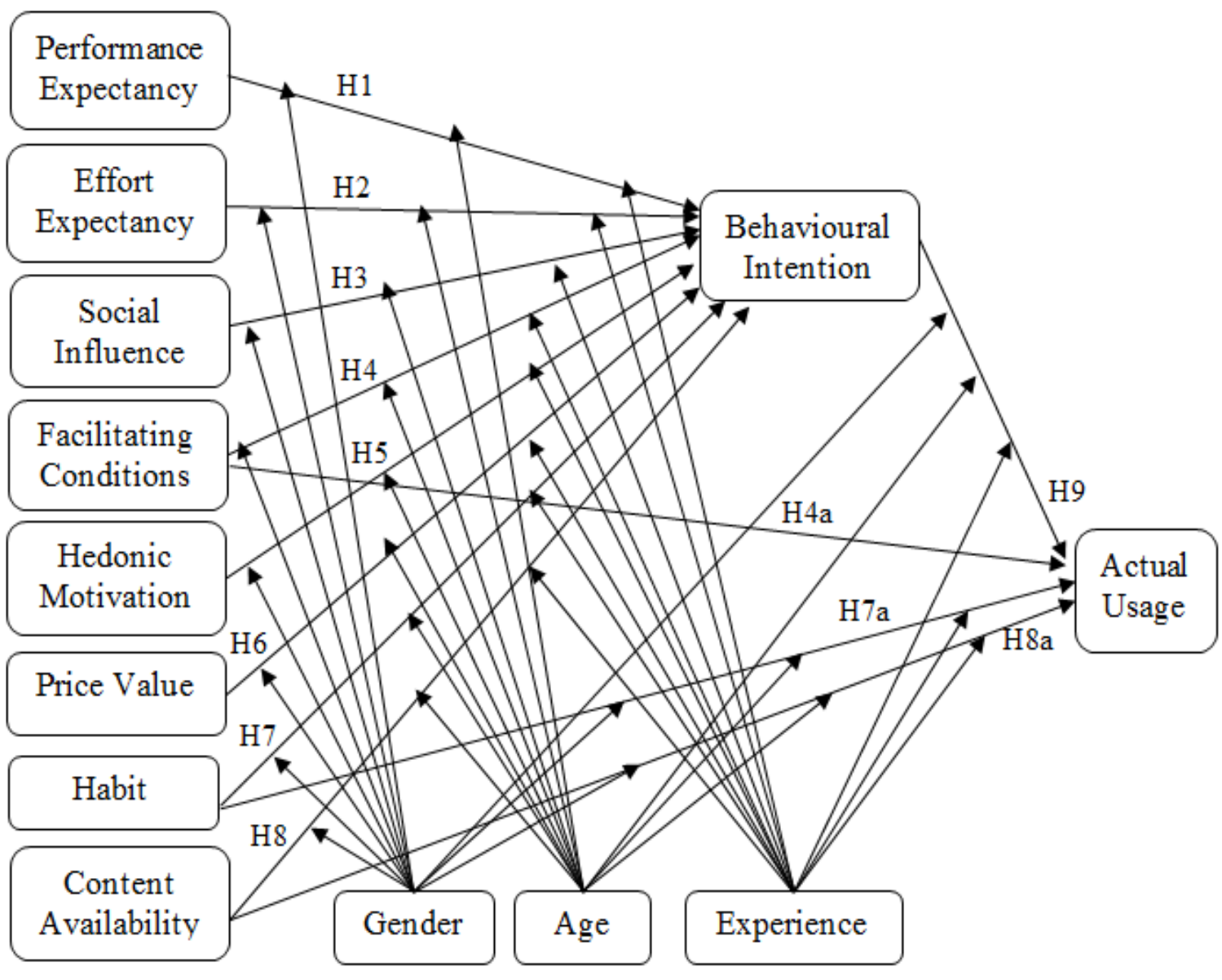

Figure No. 1: Proposed Research Model based on UTAUT2

\section{DATA ANALYSIS AND FINDINGS}

The demographics profile of the respondent is presented in table no. 2. As evident from the demographic details, bias generating due to saturation of respondents in a single category has been avoided. 
Table No. 2: Respondents Profile

\begin{tabular}{|l|c|c|c|}
\hline Demographic Variable & Category & No. of Respondents & Percentage \\
\hline Age & $17-25$ & 151 & $54.5 \%$ \\
(in Years) & Above 25 & 126 & $45.5 \%$ \\
\hline \multirow{2}{*}{ Gender } & Male & 166 & $60 \%$ \\
& Female & 111 & $40 \%$ \\
\hline \multirow{2}{*}{ OTT User for } & $<3$ Years & 172 & $62 \%$ \\
& $>3$ Years & 105 & $38 \%$ \\
\hline Total & & 277 & $100 \%$ \\
\hline
\end{tabular}

Source: Author's Calculation

\section{Measurement Model Assessment}

As suggested by Anderson and Gerbing (1988), the two-stage systematic procedure, for assessing the measurement model and structural model, was followed using SmartPLS 3.3.2 (Ringle et al., 2015). The first stage of the measurement model assessment is evaluating the reliability and validity of the constructs and the model. The composite reliability and convergent validity of the constructs in the measurement model is assessed using the factor loadings, Cronbach's alpha, Dillion-Goldstein's rho (rho_A), composite reliability (CR) and average variance extracted (AVE). Results of the same are represented in table no. 3 .

The factor loading of AU3 loaded in actual usage is little less than 0.7 but the item has not been deleted as the AVE and CR values of actual usage are sufficient to satisfy the criteria suggested by Hair et al., (2019) for measurement model assessment. Calculated CR and rho_A values of the constructs is greater than the minimum required value of 0.7 , leading to reason that the model has good internal reliability. Cronbach's alpha value, another check for reliability, of more than 0.7 represents good reliability. From the results of measurement model assessment, alpha values of all the constructs were more than 0.7 and hence reliability criteria were satisfied (Cronbach, 1951). Convergent validity in a model is achieved when the AVE values of constructs are more than 0.5 (Hair et al., 2019). Table No. 3 has the calculated AVE values of the constructs in this study. As evident from the AVE results, convergent validity has been achieved.

Table No. 3: Measurement Model Assessment Results

\begin{tabular}{|c|c|c|c|c|c|c|}
\hline Construct & Items & Loading/Weight & CR & Cronbach's Alpha & rho $\mathrm{A}$ & AVE \\
\hline AU & $\begin{array}{l}\text { AU1 } \\
\text { AU2 } \\
\text { AU3 }\end{array}$ & $\begin{array}{l}.896 \\
.867 \\
.691\end{array}$ & .861 & .761 & .808 & .677 \\
\hline BI & $\begin{array}{l}\text { BI1 } \\
\text { BI2 } \\
\text { BI3 }\end{array}$ & $\begin{array}{l}.923 \\
.953 \\
.922 \\
\end{array}$ & .952 & .925 & .926 & .870 \\
\hline PE & $\begin{array}{l}\text { PE1 } \\
\text { PE2 } \\
\text { PE3 } \\
\text { PE4 }\end{array}$ & $\begin{array}{l}.841 \\
.916 \\
.892 \\
.744\end{array}$ & .912 & .873 & .903 & .724 \\
\hline EE & $\begin{array}{l}\text { EE1 } \\
\text { EE2 } \\
\text { EE3 } \\
\text { EE4 }\end{array}$ & $\begin{array}{l}.903 \\
.889 \\
.869 \\
.787\end{array}$ & .921 & .885 & .888 & .745 \\
\hline SI & $\begin{array}{l}\text { SI1 } \\
\text { SI2 } \\
\text { SI3 }\end{array}$ & $\begin{array}{l}.932 \\
.946 \\
.911 \\
\end{array}$ & .95 & .921 & .924 & .864 \\
\hline FC & $\begin{array}{l}\text { FC1 } \\
\text { FC2 } \\
\text { FC3 } \\
\text { FC4 }\end{array}$ & $\begin{array}{l}.705 \\
.799 \\
.860 \\
.841\end{array}$ & .879 & .818 & .820 & .645 \\
\hline
\end{tabular}




\begin{tabular}{|c|c|c|c|c|c|c|}
\hline Construct & Items & Loading/Weight & CR & Cronbach's Alpha & rho $\mathrm{A}$ & AVE \\
\hline HM & $\begin{array}{l}\text { HM1 } \\
\text { HM2 } \\
\text { HM3 }\end{array}$ & $\begin{array}{l}.971 \\
.963 \\
.964\end{array}$ & .977 & .964 & .965. & 933 \\
\hline PV & $\begin{array}{l}\text { PV1 } \\
\text { PV2 } \\
\text { PV3 }\end{array}$ & $\begin{array}{l}.781 \\
.840 \\
.865\end{array}$ & .868 & .772 & .775 & .688 \\
\hline HBT & $\begin{array}{l}\text { HBT1 } \\
\text { HBT2 } \\
\text { HBT3 } \\
\text { HBT4 }\end{array}$ & $\begin{array}{l}.903 \\
.916 \\
.905 \\
.932\end{array}$ & .953 & .934 & 937 & .836 \\
\hline CA & $\begin{array}{l}\text { CA1 } \\
\text { CA2 } \\
\text { CA3 } \\
\text { CA4 }\end{array}$ & $\begin{array}{l}.877 \\
.892 \\
.829 \\
.672\end{array}$ & .892 & .851 & .906 & .676 \\
\hline
\end{tabular}

Source: Author's Calculation

AU: Actual Usage; BI: Behavioral Intention; PE: Performance Expectancy; EE: Effort Expectancy; SI: Social Influence; FC: Facilitating Conditions; HM: Hedonic Motivation; PV: Price Value; HBT: Habit; CA: Content Availability;

Post assessing convergent validity and reliability of the model, the discriminant validity of the model and constructs has been evaluated. Fornell-Larcker criterion and Heterotrait - Monotrait ratio of correlations (HTMT) are two criteria for the purpose of assessing discriminant validity. Fornell and Larcker (1981) suggested that if the square root of the AVE value of a construct is more than the correlation coefficient with other constructs, discriminant validity is achieved. Values shown in table no. 4, satisfies the criteria for discriminant validity, representing the achievement of discriminant validity.
HTMT approach by Henseler et al., (2015) for evaluating discriminant validity has been appreciated over the criteria suggested by Fornell and Larcker (1981). Researchers believe that HTMT approach achieves better sensitivity and specificity rate (Xia and Chengb, 2017; Rasoolimanesh et al., 2019). HTMT criteria advocates that calculated HTMT value of less than 0.9 for a construct indicates discriminant validity in the model (Gold et al., 2001; Voorhees et al., 2016).

The HTMT values for the model constructs are represent in table no. 5, and the result imply the achievement of discriminant validity. SRMR value of the measurement model (0.078) was under 0.08 indicating satisfactory model fit (Hu and Bentler, 1999).

Table No. 4: Discriminant Validity Assessment (Fornell-Larcker Criterion)

\begin{tabular}{|l|l|l|l|l|l|l|l|l|l|l|}
\hline & BI & CA & EE & FC & HBT & HM & PE & PV & SI & AU \\
\hline BI & .933 & & & & & & & & & \\
\hline CA & .573 & .822 & & & & & & & & \\
\hline EE & .664 & .505 & .863 & & & & & & & \\
\hline FC & .529 & .599 & .676 & .803 & & & & & & \\
\hline HBT & .801 & .567 & .605 & .55 & .914 & & & & & \\
\hline HM & .647 & .463 & .621 & .585 & .696 & .966 & & & & \\
\hline PE & .746 & .457 & .736 & .581 & .653 & .705 & .851 & & & \\
\hline PV & .183 & .157 & .241 & .289 & .305 & .481 & .244 & .829 & & \\
\hline SI & .549 & .391 & .57 & .442 & .548 & .507 & .525 & .231 & .93 & \\
\hline AU & .759 & .655 & .534 & .466 & .721 & .533 & .566 & .089 & .431 & .823 \\
\hline
\end{tabular}

Source: Author's Calculation 
Table No. 5: Discriminant Validity Assessment (HTMT Criterion)

\begin{tabular}{|l|c|c|c|c|c|c|c|c|c|c|}
\hline & BI & CA & EE & FC & HBT & HM & PE & PV & SI & AU \\
\hline BI & & & & & & & & & & \\
\hline CA & .579 & & & & & & & & & \\
\hline EE & .731 & .525 & & & & & & & & \\
\hline FC & .585 & .702 & .759 & & & & & & & \\
\hline HBT & .86 & .568 & .664 & .612 & & & & & & \\
\hline HM & .683 & .477 & .671 & .649 & .733 & & & & & \\
\hline PE & .803 & .471 & .818 & .661 & .704 & .743 & & & & \\
\hline PV & .215 & .192 & .296 & .386 & .36 & .556 & .287 & & & \\
\hline SI & .594 & .408 & .631 & .5 & .592 & .538 & .585 & .273 & & \\
\hline AU & .886 & .707 & .629 & .553 & .835 & .62 & .678 & .178 & .507 & \\
\hline
\end{tabular}

Source: Author's Calculation

\section{Structural Model Assessment}

Variance Inflation Factor (VIF) is a measure of absence or presence of multicollinearity issues in the model. The VIF values for all the constructs depicted in table no. 6, are in the range of 1.350-3.069. According to the standards recommended by Diamantopoulos and Siguaw (2006), VIF values less than 3.33, and according to the norms advised by Hair et al., (2017), VIF values less than 5 confirms the absence multi collinearity issues (Diamantopoulos and Siguaw, 2006). Hence it is observed that no multicollinearity issues are prevalent in the model.

Bootstrapping analysis with a sample size of 5000 was used for testing the hypotheses of the study. Results report that, performance expectancy $(\beta=0.322, t=5.717)$, price value $(\beta$ $=-0.088, \mathrm{t}=2.551)$, habit $(\beta=0.480, \mathrm{t}=8.490)$ and content availability $(\beta=0.135, \mathrm{t}=3.295)$ significantly influenced behavioral intention of respondent for using OTT. Effort expectancy $(\beta=0.100, t=1.703)$, social influence $(\beta=$ $0.051, \mathrm{t}=0.852)$, facilitating conditions $(\beta=$ -
$0.083, \mathrm{t}=1.459)$ and hedonic motivation $(\beta=$ $0.026, t=0.37$ ) has no influence on behavioral intention of using OTT. With respect to actual usage of OTT video streaming platforms, behavioral intention $(\beta=0.419, \mathrm{t}=6.921)$, facilitating conditions $(\beta=-0.089, \mathrm{t}=2.066)$, habit $(\beta=0.249, \mathrm{t}=4.331)$ and content availability $(\beta=0.327, \mathrm{t}=6.394)$ had significant impact on actual use behavior.

After the hypothesis testing, the value of coefficient of determination $\left(\mathrm{R}^{2}\right)$ was evaluated. The calculated $\mathrm{R}^{2}$ value of behavioral intention is .753 and actual usage is .670. These values are significantly above 0.26 , which infers substantial predictive precision of the model (Cohen, 1988). The adjusted $R^{2}$ considers the number of predictors in the model and adjusts $\mathrm{R}^{2}$ value accordingly. The calculated $R^{2}$ value for behavioral intention is .746 and for actual usage is .666. The $\mathrm{R}^{2}$ values are the functions of the number of predictor constructs and generally increases with the number of predictors in the study (Shiva et al., 2020.)

Table No. 6: Inner VIF Values of Model

\begin{tabular}{|c|c|c|c|c|c|c|c|c|c|c|}
\hline & BI & CA & EE & FC & HBT & HM & PE & PV & SI & UB \\
\hline BI & & & & & & & & & & 2.985 \\
\hline CA & 1.807 & & & & & & & & & 1.85 \\
\hline EE & 2.962 & & & & & & & & & \\
\hline FC & 2.337 & & & & & & & & & 1.751 \\
\hline HBT & 2.567 & & & & & & & & & 3.024 \\
\hline HM & 3.069 & & & & & & & & & \\
\hline PE & 2.959 & & & & & & & & & \\
\hline PV & 1.35 & & & & & & & & & \\
\hline SI & 1.663 & & & & & & & & & \\
\hline UB & & & & & & & & & & \\
\hline
\end{tabular}

Source: Author's Calculation 
Table No. 7: Hypothesis Testing Results

\begin{tabular}{|l|l|c|c|c|c|c|}
\hline & Relationship & Std. $\boldsymbol{\beta}$ & t-statistics & Confidence Interval & $\begin{array}{c}\text { Effect Size } \\
\left(\mathbf{f}^{2}\right)\end{array}$ & $\begin{array}{c}\text { Hypothesis } \\
\text { Supported }\end{array}$ \\
\hline H1 & PE $\rightarrow$ BI & 0.322 & 5.717 & {$[0.209,0.426]$} & 0.142 & Yes \\
\hline H2 & EE $\rightarrow$ BI & 0.100 & 1.703 & {$[-0.014,0.217]$} & 0.014 & No \\
\hline H3 & SI $\rightarrow$ BI & 0.051 & 0.852 & {$[-0.071,0.163]$} & 0.006 & No \\
\hline H4 & FC $\rightarrow$ BI & -0.083 & 1.459 & {$[-0.194,0.031]$} & 0.012 & No \\
\hline H5 & HM $\rightarrow$ BI & 0.026 & 0.370 & {$[-0.112,0.156]$} & 0.001 & No \\
\hline H6 & PV $\rightarrow$ BI & -0.088 & 2.551 & {$[-0.162,-0.029]$} & 0.023 & Yes \\
\hline H7 & HBT $\rightarrow$ BI & 0.480 & 8.490 & {$[0.366,0.585]$} & 0.364 & Yes \\
\hline H8 & CA $\rightarrow$ BI & 0.135 & 3.295 & {$[0.056,0.219]$} & 0.041 & Yes \\
\hline H9 & BI $\rightarrow$ AU & 0.419 & 6.921 & {$[0.288,0.529]$} & 0.179 & Yes \\
\hline H4a & FC $\rightarrow$ AU & -0.089 & 2.066 & {$[-0.174,-0.007]$} & 0.014 & Yes \\
\hline H7a & HBT $\rightarrow$ AU & 0.249 & 4.331 & {$[0.140,0.364]$} & 0.062 & Yes \\
\hline H8a & CA $\rightarrow$ AU & 0.327 & 6.394 & {$[0.230,0.431]$} & 0.176 & Yes \\
\hline
\end{tabular}

Source: Author's Calculation

Table No. 8: Coefficients of Determination $\left(\mathbf{R}^{2}\right)$ and Adjusted $\mathbf{R}^{2}$

\begin{tabular}{|l|l|l|}
\hline & $\mathbf{R}^{\mathbf{2}}$ & Adjusted $\mathbf{R}^{\mathbf{2}}$ \\
\hline Actual Usage & 0.670 & 0.666 \\
\hline Behavioral Intention & 0.753 & 0.746 \\
\hline
\end{tabular}

Source: Author's Calculation

Cohen (1988) proposed measuring effect size $\left(\mathrm{f}^{2}\right)$ of construct which indicates the statistical magnitude of a construct. According to this proposition, effect size $\left(\mathrm{f}^{2}\right)$ value of more than 0.35 implies huge effect size, $0.15-0.35$ implies moderate effect size and less than 0.15 implies minor effect size. With reference to behavioral intention habit $\left(\mathrm{f}^{2}=0.364\right)$ had a huge size effect while performance expectancy $\left(\mathrm{f}^{2}=\right.$ 0.142) had a low effect size. Rest of the construct had low to negligible effect size evident from the $\mathrm{f}^{2}$ values reported in table no. 7. For actual usage of OTT, content availability $\left(\mathrm{f}^{2}=0.176\right)$ and behavioral intention $\left(\mathrm{f}^{2}=0.179\right)$ had moderate effect size. Facilitating condition $\left(\mathrm{f}^{2}=0.014\right)$ and habit $\left(\mathrm{f}^{2}=0.062\right)$ had low effect size. The standard root means square residual value (SRMR) for the model was 0.079, less than 0.08 which showed acceptable model fit (Hu and Bentler, 1999; Sarstedt et al., (2020)).

Table No. 9: Predictive Relevance $\left(\mathrm{Q}^{2}\right)$

\begin{tabular}{|l|c|}
\hline & Calculated $\mathbf{Q}^{\mathbf{2}}$ \\
\hline Actual Usage & 0.441 \\
\hline Behavioral Intention & 0.643 \\
\hline
\end{tabular}

Source: Author's Calculation

In the last step of analysis, predictive relevance was calculated using blindfolding technique, with an omission distance of nine. The results were assessed using Stone-
Geisser's Q2 value (Geisser, 1974; Stone, 1974). The calculated $\mathrm{Q}^{2}$ value for actual usage was .441 and behavioral intention was .643 which was significantly more than zero. Hence it was established that the model had satisfactory predictive relevance.

\section{Moderating Effect of Gender, Age and Experience \\ PLS Multigroup Analysis (MGA) is used to} study the moderating effect of three demographic variables of respondents, gender, age and experience (years using OTT). The study theorized that, these three demographics variables moderate the relation of behavioral intention with performance expectancy, effort expectancy, social influence, facilitating conditions, habit, price value, hedonic motivation and content availability. In the context of actual usage, it has been hypothesized that gender, age and experience moderate the relationship of actual usage with habit, behavioral intention and content availability.

\section{Moderating Role of Gender}

First MGA analysis had gender playing the role of moderator. 60 percent of the respondents are male while 40 percent are female. The $\mathrm{R}^{2}$ value for male respondents (behavioral intention $=0.826$, actual usage $=$ $0.726)$ was more compared to $R^{2}$ value for female respondents (behavioral intention $=$ 0.782 , actual usage $=0.621$ ). The results of MGA also suggest that hedonic motivation and social influence play a significant role in determining female's behavioral intentions of using OTT, while male respondents are not 
influenced by the same. As evident from the $t$ values and significance reported in table no. 10, gender moderates the relationship of behavioral intention with content availability and effort expectancy, as well as, the relation between habit and use behavior. Performance expectancy is more important for women and their actual usage is significantly influenced by their intentions to use. Men, more than women, are motivated by their habit and content availability when using OTT video streaming platforms.

\section{Moderating Role of Age}

Next, the moderating effect of age was evaluated. 54.5 percent of respondents are 1725 years of age while the rest are older than 25 years. The $\mathrm{R}^{2}$ value for respondents between 17-25 years (behavioral intention $=0.774$, actual usage $=0.683$ ) was almost equal to $\mathrm{R}^{2}$ value for respondents above 25 years (behavioral intention $=0.760$, actual usage $=$ 0.686 ). In the context of behavioral intention, the users falling between 17-25 years are more influenced by their habit and effort expectancy, as evident from their $t$-values and p-values reported in table no. 11. For users above 25 years, performance, price value and content availability are more reliable for their intentions to use OTT video streaming platforms. Users below the age of 25 depend on habit and facilitating conditions for their actual usage while content availability, though significant for both age groups, is more critical for users aged 17-25. The people above 25 years of age have strong tendency of actual use of OTT video streaming platforms once intended to do so, as evident from the path coefficient value being three time as compared to users aged $17-25$ years.

\section{Moderating Role of Experience}

$62 \%$ of the respondents have an experience of using OTT media platform for less than three years while $38 \%$ of the respondents have been using OTT media streaming platforms for more than three years. There was a significant difference observed in the $\mathrm{R}^{2}$ value of actual usage for respondents who had been using it for more than three years (behavioral intention $=0.744$, actual usage $=0.736$ ) against respondents who had been using it for lesser time (behavioral intention $=0.773$, actual usage $=0.660)$. Habit is a significant contributor in user's intention to use OTT but the actual usage of users who have been using OTT media platform for more than three years is not dependent on their habit. As evident from the values reported in table no. 12, intentions of more experienced users rely on the magnitude of effort required, availability of content and the fun or joy received from availing the services. The same is not reflected in the intentions of less experienced users. Content availability and performance is significant for defining the use behavior of all users, but their influence is more on the technology usage of less experienced users. The intentions to use and the tendency to use the OTT video streaming platforms is twice in users with more experience compared to users with less experience.

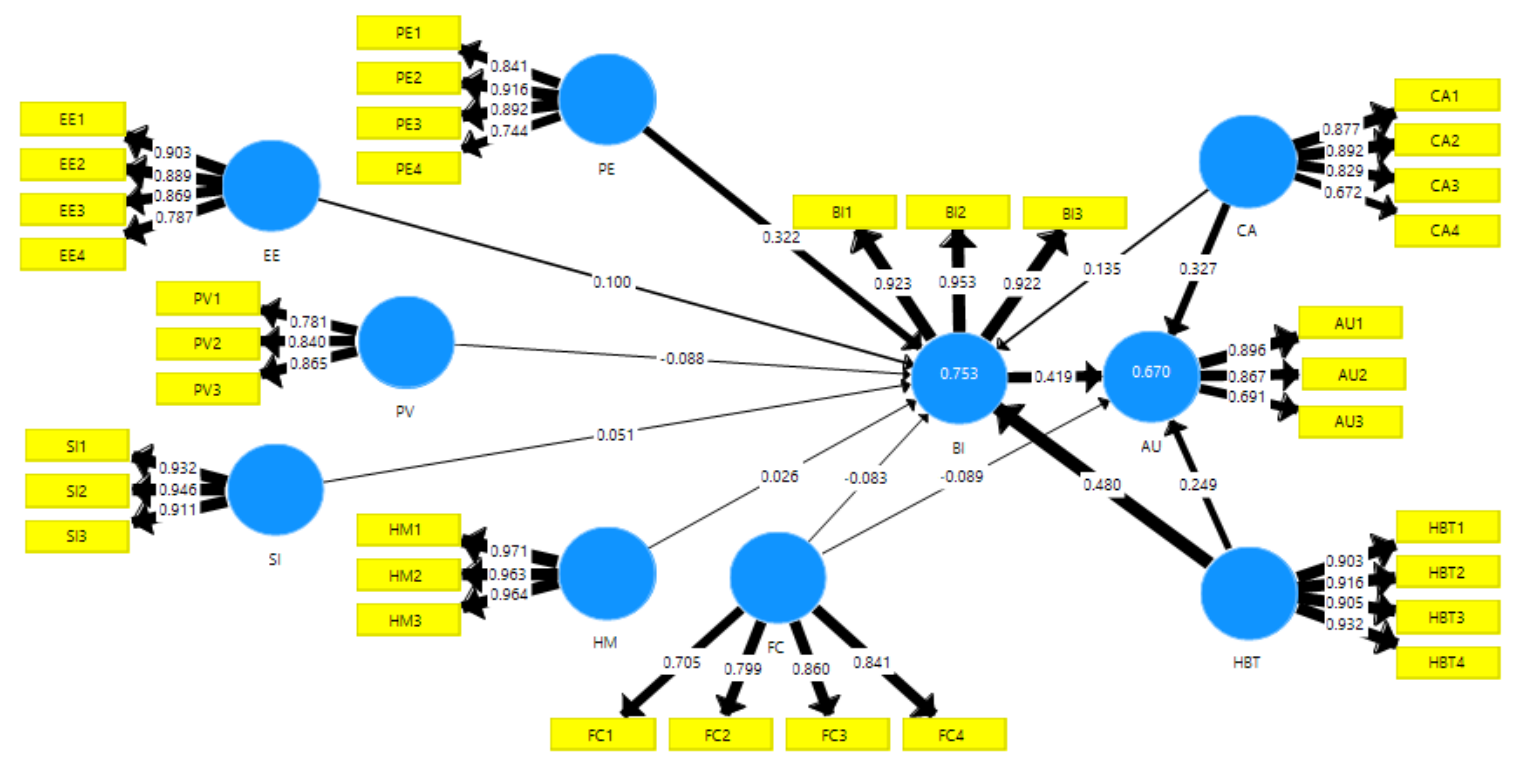

Figure 2: Path Analysis Results of Structural Model 
Theoretical Implications

The study was an attempt towards testing the acceptance of OTT video streaming platforms using UTAUT2 model. The study tries to understand the impact of constructs of UTAUT2 model on BI. The results of the path analysis reveal that performance expectancy, price value, habit and content availability have a significant impact on the BI of OTT video streaming platform users.

Table No. 10: Moderating Effect of Gender - MGA

\begin{tabular}{|c|c|c|c|c|c|c|c|c|c|c|}
\hline & \begin{tabular}{|c|} 
Path \\
Coefficients \\
Original \\
(Female)
\end{tabular} & \begin{tabular}{|c|} 
Path \\
Coefficients \\
Original \\
(Male)
\end{tabular} & \begin{tabular}{|c} 
Path \\
Coefficients \\
Mean \\
(Female)
\end{tabular} & $\begin{array}{c}\text { Path } \\
\text { Coefficients } \\
\text { Mean } \\
\text { (Male) }\end{array}$ & $\begin{array}{l}\text { STDEV } \\
\text { (Female) }\end{array}$ & $\begin{array}{l}\text { STDEV } \\
\text { (Male) }\end{array}$ & $\begin{array}{l}\mathrm{t} \text {-Value } \\
\text { (Female) }\end{array}$ & $\begin{array}{c}\mathrm{t} \text {-Value } \\
\text { (Male) }\end{array}$ & $\begin{array}{l}\mathrm{p} \text {-Value } \\
\text { (Female) }\end{array}$ & $\begin{array}{l}\text { p-Value } \\
\text { (Male) }\end{array}$ \\
\hline $\mathrm{BI} \rightarrow \mathrm{UB}$ & 0.409 & 0.364 & 0.4 & 0.358 & 0.09 & 0.085 & 4.53 & 4.256 & 0.000 & 0.000 \\
\hline $\mathrm{CA} \rightarrow \mathrm{BI}$ & 0.131 & 0.149 & 0.124 & 0.149 & 0.054 & 0.049 & 2.418 & 3.019 & 0.016 & 0.003 \\
\hline $\mathrm{CA} \rightarrow \mathrm{UB}$ & 0.258 & 0.381 & 0.262 & 0.381 & 0.076 & 0.067 & 3.38 & 5.667 & 0.001 & 0.000 \\
\hline $\mathrm{EE} \rightarrow \mathrm{BI}$ & 0.168 & 0.162 & 0.162 & 0.179 & 0.075 & 0.076 & 2.221 & 2.121 & 0.026 & 0.034 \\
\hline $\mathrm{FC} \rightarrow \mathrm{BI}$ & -0.046 & -0.089 & -0.031 & -0.089 & 0.07 & 0.07 & 0.661 & 1.266 & 0.509 & 0.206 \\
\hline $\mathrm{FC} \rightarrow \mathrm{UB}$ & -0.024 & -0.074 & -0.021 & -0.071 & 0.065 & 0.058 & 0.365 & 1.279 & 0.715 & 0.201 \\
\hline $\mathrm{HBT} \rightarrow \mathrm{BI}$ & 0.318 & 0.49 & 0.327 & 0.487 & 0.085 & 0.057 & 3.718 & 8.578 & 0.000 & 0.000 \\
\hline HBT $\rightarrow$ UB & 0.269 & 0.264 & 0.278 & 0.27 & 0.087 & 0.083 & 3.11 & 3.174 & 0.002 & 0.002 \\
\hline $\mathrm{HM} \rightarrow \mathrm{BI}$ & -0.426 & 0.145 & -0.403 & 0.132 & 0.096 & 0.08 & 4.459 & 1.816 & 0.000 & 0.070 \\
\hline $\mathrm{PE} \rightarrow \mathrm{BI}$ & 0.612 & 0.237 & 0.591 & 0.232 & 0.087 & 0.075 & 7.013 & 3.142 & 0.000 & 0.002 \\
\hline $\mathrm{PV} \rightarrow \mathrm{BI}$ & 0.032 & -0.073 & 0.027 & -0.063 & 0.078 & 0.054 & 0.414 & 1.371 & 0.679 & 0.170 \\
\hline
\end{tabular}

Source: Author's Calculation

Table No. 11: Moderating Effect of Age - MGA

\begin{tabular}{|c|c|c|c|c|c|c|c|c|c|c|}
\hline & \begin{tabular}{|c|} 
Path \\
Coefficients \\
Original \\
$(17-25)$
\end{tabular} & \begin{tabular}{|c|} 
Path \\
Coefficients \\
Original \\
(Above 25)
\end{tabular} & \begin{tabular}{|c|} 
Path \\
Coefficients \\
Mean \\
$(17-25)$ \\
\end{tabular} & \begin{tabular}{|c|} 
Path \\
Coefficients \\
Mean \\
(Above 25)
\end{tabular} & $\begin{array}{l}\text { STDEV } \\
(17-25)\end{array}$ & $\begin{array}{c}\text { STDEV } \\
\text { (Above 25) }\end{array}$ & $\begin{array}{l}\mathrm{t}-\text { Value } \\
(17-25)\end{array}$ & $\begin{array}{c}\mathrm{t} \text {-Value } \\
\text { (Above 25) }\end{array}$ & $\begin{array}{c}\text { p-Value } \\
(17-25)\end{array}$ & $\begin{array}{c}\mathrm{p} \text {-Value } \\
\text { (Above 25) }\end{array}$ \\
\hline $\mathrm{BI} \rightarrow \mathrm{UB}$ & 0.203 & 0.652 & 0.2 & 0.65 & 0.082 & 0.064 & 2.486 & 10.26 & 0.013 & 0.000 \\
\hline $\mathrm{CA} \rightarrow \mathrm{BI}$ & 0.055 & 0.193 & 0.061 & 0.185 & 0.057 & 0.056 & 0.969 & 3.466 & 0.333 & 0.001 \\
\hline $\mathrm{CA} \rightarrow \mathrm{UB}$ & 0.428 & 0.177 & 0.429 & 0.18 & 0.069 & 0.075 & 6.179 & 2.373 & 0.000 & 0.018 \\
\hline $\mathrm{EE} \rightarrow \mathrm{BI}$ & 0.162 & -0.011 & 0.167 & 0.006 & 0.055 & 0.117 & 2.915 & 0.09 & 0.004 & 0.928 \\
\hline $\mathrm{FC} \rightarrow \mathrm{BI}$ & -0.007 & -0.119 & -0.011 & -0.111 & 0.066 & 0.095 & 0.099 & 1.26 & 0.921 & 0.208 \\
\hline $\mathrm{FC} \rightarrow \mathrm{UB}$ & -0.131 & -0.012 & -0.128 & -0.016 & 0.053 & 0.06 & 2.488 & 0.192 & 0.013 & 0.847 \\
\hline $\mathrm{HBT} \rightarrow \mathrm{BI}$ & 0.562 & 0.424 & 0.547 & 0.432 & 0.078 & 0.09 & 7.25 & 4.72 & 0.000 & 0.000 \\
\hline $\begin{array}{l}\mathrm{HBT} \rightarrow \\
\mathrm{UB}\end{array}$ & 0.405 & 0.083 & 0.407 & 0.091 & 0.081 & 0.073 & 4.995 & 1.136 & 0.000 & 0.256 \\
\hline $\mathrm{HM} \rightarrow \mathrm{BI}$ & -0.076 & 0.11 & -0.083 & 0.068 & 0.087 & 0.126 & 0.875 & 0.874 & 0.382 & 0.382 \\
\hline $\mathrm{PE} \rightarrow \mathrm{BI}$ & 0.266 & 0.375 & 0.277 & 0.382 & 0.075 & 0.101 & 3.543 & 3.72 & 0.000 & 0.000 \\
\hline $\mathrm{PV} \rightarrow \mathrm{BI}$ & -0.104 & -0.148 & -0.077 & -0.133 & 0.085 & 0.053 & 1.232 & 2.793 & 0.218 & 0.005 \\
\hline
\end{tabular}

Source: Author's Calculation

Table No. 12: Moderating Effect of User Experience - MGA

\begin{tabular}{|c|c|c|c|c|c|c|c|c|c|c|}
\hline & $\begin{array}{c}\text { Path } \\
\text { Coefficients } \\
\text { Original } \\
\text { (<3 Years) }\end{array}$ & \begin{tabular}{|c|} 
Path \\
Coefficients \\
Original \\
(>3 years)
\end{tabular} & \begin{tabular}{|c|} 
Path \\
Coefficients \\
Mean \\
(<3 Years)
\end{tabular} & $\begin{array}{c}\text { Path } \\
\text { Coefficients } \\
\text { Mean } \\
\text { (>3 years) }\end{array}$ & $\begin{array}{c}\text { STDEV } \\
(<3 \\
\text { Years })\end{array}$ & $\begin{array}{c}\text { STDEV } \\
\text { (>3 years) }\end{array}$ & $\begin{array}{c}\mathrm{t}-\text { Value } \\
(<3 \text { Years })\end{array}$ & $\begin{array}{c}\mathrm{t}-\text { Value } \\
(>3 \text { years })\end{array}$ & $\underset{(<3 \text { Years })}{p-\text { Value }}$ & $\begin{array}{c}p \text {-Value } \\
(>3 \text { years })\end{array}$ \\
\hline $\mathrm{BI} \rightarrow \mathrm{UB}$ & 0.297 & 0.607 & 0.288 & 0.593 & 0.081 & 0.086 & 3.641 & 7.07 & 0.000 & 0.000 \\
\hline $\mathrm{CA} \rightarrow \mathrm{BI}$ & 0.092 & 0.224 & 0.092 & 0.217 & 0.052 & 0.084 & 1.777 & 2.666 & 0.076 & 0.008 \\
\hline $\mathrm{CA} \rightarrow \mathrm{UB}$ & 0.362 & 0.251 & 0.363 & 0.241 & 0.06 & 0.103 & 5.983 & 2.449 & 0.000 & 0.014 \\
\hline $\mathrm{EE} \rightarrow \mathrm{BI}$ & 0.092 & 0.224 & 0.101 & 0.224 & 0.07 & 0.086 & 1.316 & 2.608 & 0.188 & 0.009 \\
\hline $\mathrm{FC} \rightarrow \mathrm{BI}$ & -0.119 & 0.057 & -0.119 & 0.062 & 0.065 & 0.081 & 1.817 & 0.701 & 0.069 & 0.483 \\
\hline $\mathrm{FC} \rightarrow \mathrm{UB}$ & -0.119 & -0.066 & -0.118 & -0.057 & 0.051 & 0.089 & 2.305 & 0.746 & 0.021 & 0.456 \\
\hline $\mathrm{HBT} \rightarrow \mathrm{BI}$ & 0.473 & 0.3 & 0.469 & 0.305 & 0.075 & 0.112 & 6.311 & 2.674 & 0.000 & 0.008 \\
\hline $\mathrm{HBT} \rightarrow \mathrm{UB}$ & 0.355 & 0.139 & 0.364 & 0.156 & 0.073 & 0.085 & 4.882 & 1.644 & 0.000 & 0.100 \\
\hline $\mathrm{HM} \rightarrow \mathrm{BI}$ & 0.113 & -0.272 & 0.096 & -0.272 & 0.08 & 0.102 & 1.413 & 2.676 & 0.158 & 0.008 \\
\hline $\mathrm{PE} \rightarrow \mathrm{BI}$ & 0.341 & 0.256 & 0.346 & 0.257 & 0.089 & 0.055 & 3.825 & 4.634 & 0.000 & 0.000 \\
\hline $\mathrm{PV} \rightarrow \mathrm{BI}$ & -0.059 & -0.082 & -0.049 & -0.043 & 0.047 & 0.098 & 1.27 & 0.832 & 0.204 & 0.406 \\
\hline
\end{tabular}

Source: Author's Calculation 
The results are in line with the previous studies (Yuan et al., 2015; Gupta et al., 2017; Kwateng et al., 2019; Shaw and Sergueeva, 2019; Ramírez-Correa et al., 2019; Duarte and Pinho, 2019; Alalwan, 2020). Also, the results of the hypothesis testing report that behavioural intention, content availability, habit and facilitating conditions leads to the actual usage of OTT video streaming platforms in Indian context.

The results of the study contribute to the body of literature of OTT video streaming platforms in context of emerging Indian market in the field. The UTAUT2 model has been of the interest of the researchers since its inception in year 2012 and acceptance of many technologies such as $\mathrm{m}$ payments (Tak and Panwar, 2017; Hussian et al., 2019), e - learning (Tarhini et al., 2017; Samsudeen and Mohamed, 2019), social media apps (Praveena and Thomas, 2018, Shiva et al., 2020), tourism apps (Gupta et al., 2018) health apps (Yuan et al., 2015) etc. has been studies extensively. OTT video streaming platforms have not established the attention of the scholars so far. Thus, the study contributes in understanding the technological acceptance and use behaviour of OTT video streaming platforms by extending the UTAUT2 model by Venkatesh et al., (2012).

\section{Managerial Implication}

The study gives the insight and confirms that performance expectancy, habit, content availability and price value are the top four forecasters of intention to use for OTT video streaming platforms. The managers should consider these points and assure to offers the customers with more content options in form of original series. The mangers can also offer the same content in different local or regional language by understanding the market segmentation. This will help in grabbing the attention of more viewers towards the OTT video streaming platforms. The Price value plays a significant role in developing the intention to use any service and same is the case reported by the results of this study regarding the OTT media platforms. The manager should offer the value packs and benefits at lower price to increase the intention of customers to subscribe to the OTT video streaming platforms. The results also advocate that habit plays a very strong role towards intention of adoption of a technology. The managers can initially offer the services for free developing the habit to intent to use the OTT video streaming platforms. The constructs such as effort expectancy, social influence, facilitating conditions and hedonic motivation were not reported significant in affecting the consumers intention to adopt OTT video streaming platforms. The reasons with respect to why the these UTAUT 2 model constructs, were not significant in influencing consumers BI to receive and utilize technology should be tended to by connecting more in OTT video streaming platform refinement programs with smart phone clients.

The significant impact of facilitating conditions, habit, content availability and behavioural intention was also reported to the actual usage of OTT video streaming platforms. Behavioral intention is a strong predictor of actual usage for OTT video streaming platforms.

The consumers who have an intention will at some point use the OTT video streaming platforms. Though facilitating condition such as the availability of technological infrastructure to facilitate the usage of OTT video streaming platforms do not play a signification role in the developing the intention to use but has a relationship while using the application. The managers should ensure that the OTT video streaming platforms should operate with the minimum infrastructural requirement such as internet, smartphone device specifications, registration process etc. habit and content availability also have strong impact towards the actual usage by the customers.

The moderating role of gender, age and experience towards intention and actual use suggest that customers with different gender, age and experience behave differently and have their own priorities while adopting a technology as they moderate on UTAUT2 model constructs. The results of the study will help the managers in comprehending and devising different strategies for consumers of different age and experience. The marketing plan for the prospective OTT subscribes can be framed keeping in view the results of this study while targeting the segment of customers in terms of male - female, young and middle-aged customers, loyal and new customers. 


\section{Limitations and Future Scope}

The study as all other studies was bound by some limitation, considering these limitations, the scope for the future researchers is mentioned. First the study has extended the UTAUT2 model with content validity, the future researchers can consider other factors such as net neutrality, Internet penetrations etc. Second, the future researchers can consider the moderating effect of education qualification on BI and $A U$ in their study. Lastly, the sample selected for this study were the active user of OTT video streaming platforms of India, therefore the findings of the study are limited by its geographic restrictions. The users of different country and culture may possess different opinion regarding the use of OTT video streaming platforms. Thus, future researchers can take the cross-cultural studies to understand the same.

\section{CONCLUSION}

The study accomplishes that the key drivers of adopting and using OTT video streaming platforms are performance expectancy, price value, habit and content availability. The study confirms the relevance of UTAUT2 model in the present context. The study also explains the moderating role of gender, experience and age in UTAUT2 model constructs with respect to OTT video streaming platforms. How the insignificant constructs can be focused has also been explained to increase the subscribers of OTT video streaming platforms.

\section{REFERENCES}

Alalwan, A. A. (2020), “Mobile food ordering apps: An empirical study of the factors affecting customer e-satisfaction and continued intention to reuse", International Journal of Information Management, Vol. 50, pp. 28-44.

Anderson, J. C., and Gerbing, D. W. (1988), "Structural equation modeling in practice: a review and recommended two-step approach", Psychological Bulletin, Vol. 103 No. 3, pp. 411-423.

Begum, F. (2018). In India, localized content is as important as pricing when choosing a video service - IHS Technology. Retrieved January 30, 2020
Bentley, F., Silverman, M., and Bica, M. (2019, June), "Exploring online video watching behaviours", In Proceedings of the 2019 ACM International Conference on Interactive Experiences for $T V$ and Online Video, pp. 108-117.

Business Standard. Covid-19 spells disaster for film industry but boosts digital media: KPMG. Published online on $14^{\text {th }}$ April 2020. Available at : https://www.businessstandard.com/article/companies/covid -19-spells-disaster-for-film-industry-butboosts-digital-media-kpmg120041400383_1.html

Business Standard. Race for digital-first film releases hots up on OTTs after GulaboSitabo. Published online on $16^{\text {th }}$ June 2020. Available at. https://www.businessstandard.com/article/companies/racefor-digital-first-film-releases-hots-up-onotts-after-gulabo-sitabo120061601872_1.html

Chen, Y. N. K. (2019), “Competitions between OTT TV platforms and traditional television in Taiwan: A Niche analysis", Telecommunications Policy, Vol. 43 No. 9, pp. 101793.

Cohen, J. (1988), “Statistical power analysis for the behavioral sciences", (2nd ed), Hillsdale, NJ: Lawrence Erlbaum Associates.

Denzin, N.K. and Lincoln, Y.S. (2005), "Introduction: the discipline and practice of qualitative research", in Denzin, N.K. and Lincoln, Y.S. (Eds), The Sage Handbook of Qualitative Research, Sage.

Diamantopoulos, A., and Siguaw, D. (2006), "Formative Versus Reflective Indicators in Organizational Measure Development: A Comparison and Empirical Illustration", British Journal of Management, Vol. 17 No. 4, pp. 263-282.

Duarte, P., and Pinho, J. C. (2019), "A mixed methods UTAUT2-based approach to assess mobile health adoption", Journal of Business Research, Vol. 102, pp. 140150.

Erman, J., Gerber, A., Ramadrishnan, K. K., Sen, S., and Spatscheck, O. (2011, 
November), "Over the top video: the gorilla in cellular networks", In Proceedings of the 2011 ACM SIGCOMM conference on Internet measurement conference, pp. 127-136.

ET Brand Equity.com. Gaming and OTT spike in COVID-19 lockdown: Publicis Report. Published online on $16^{\text {th }}$ April 2020. Available at: https://brandequity.economictimes.ind iatimes.com/news/media/gaming-andott-spike-in-covid-19-lockdownpublicis-report/75173664

Farooq, M. S., Salam, M., Jaafar, N., Fayolle, A., Ayupp, K., Radovic-Markovic, M., and Sajid, A. (2017), "Acceptance and use of lecture capture system (LCS) in executive business studies", Interactive Technology and Smart Education.

Fitzgerald, S. (2019), “Over-the-Top Video Services in India: Media Imperialism after Globalization", Media Industries Journal, Vol. 6 No. 1, pp. 00-00.

Fornell, C., and Larcker, D. F. (1981), "Evaluating structural equation models with unobservable variables and measurement error", Journal of Marketing Research, Vol. 18 No. 1, pp. 39-50.

Geisser, S. (1974), "A predictive approach to the random effect model", Biometrika, Vol. 61 No. 1, pp. 101-107.

Gevers, A. (2019). Video Streaming in India: Hot hothot! Comscore, Inc. Retrieved February 3, 2020, from https://www.comscore.com/Insights/ Blog/Video-Streaming-in-India.

Gold, A. H., Malhotra, A., and Segars, A. H. (2001), "Knowledge management: An organizational capabilities perspective", Journal of Management Information Systems, Vol. 18 No. 1, pp. 185-214.

Gonçalves, V., Evens, T., Alves, A. P., and Ballon, P. (2014), "Power and control strategies in online video services".

Gupta, A., Dogra, N., and George, B. (2018), "What determines tourist adoption of smartphone apps?", Journal of Hospitality and Tourism Technology.

Hair, J. F., Howard, M. C., and Nitzl, C. (2020). "Assessing measurement model quality in PLS-SEM using confirmatory composite analysis". Journal of Business Research, Vol. 109, pp. 101-110.

Hair, J. F., Risher, J. J., Sarstedt, M., and Ringle, C. M. (2019). "When to use and how to report the results of PLS-SEM". European Business Review, Vol. 31, No. 1, pp. 2-24

Haryoto, K. S. (2015), “The use of modified theory of acceptance and use of technology 2 to predict prospective users' intention in adopting TV Streaming".

Henseler, J., Ringle, C. M. and Sarstedt, M. (2015). "A new criterion for assessing discriminant validity in variance-based structural equation modelling", Journal of the Academy of Marketing Science, Vol. 43 No. 1, pp. 115-135.

https://technology.ihs.com/609737/in-indialocalized-content-is-as-important-aspricing-when-choosing-a-video-service.

https://www.ibef.org/news/indias-onlinevideo-market-to-touch-us-4-billion-by2025 Accessed on 21 ${ }^{\text {st }}$ June 2020.

Hu, L. T., and Bentler, P. M. (1999), "Cutoff criteria for fit indexes in covariance structure analysis: Conventional criteria versus new alternatives", Structural equation modeling: a multidisciplinary journal, Vol. 6 No. 1, pp. 1-55.

IBEF. ZEE invests Rs 522 crore in tech startup SugarBox. Published online on $13^{\text {th }}$ April 2020. Available at : https://www.ibef.org/news/zeeinvests-rs-522-crore-in-tech-startupsugarbox

Jirakasem, M., and Mitomo, H. (2019), "Relationship of Over-the-top (OTT) Communications and Traditional Telecommunications Services: the Case of Thailand".

Joy, T., and Bahl, S. (2018), "Disruption by reliance jio in telecom industry", International Journal of Pure and Applied Mathematics, Vol. 118 No. 20, pp. 43-49.

Kwateng, K. O., Atiemo, K. A. O., and Appiah, C. (2019), "Acceptance and use of mobile banking: an application of UTAUT2", Journal of enterprise information management. 
Li, S. C. S. (2017), “Television media old and new: A niche analysis of OTT, IPTV, and digital cable in Taiwan", Telematics and Informatics, Vol. 34 No. 7, pp. 1024-1037.

Mairaru, S., Tyagi, S., Azeez, C., and Sharma, D. C. (2019). "Understanding the Print, Web, Television Media Habits and Preferences of Indians: A Uses and Gratification Perspective" Journal of Content, Community and Communication, Vol. 9 No. 1, pp. 75-80.

Ogidiaka, E., and Ogwueleka, F. N. (2019), "Over-The-Top Services (OTT) on telecommunication operators in Nigeria: exploring consumers' behaviour", International Journal of Information Technology, pp. 1-10.

Oliveira, T., Thomas, M., Baptista, G., and Campos, F. (2016), "Mobile payment: Understanding the determinants of customer adoption and intention to recommend the technology", Computers in Human Behavior, Vol. 61, pp. 404-414.

Praveena, K., and Thomas, S. (2018), "Explaining user acceptance and usage of social networking sites: the role of trust, social connectedness and visibility in extending UTAUT2", International Journal of Management Practice, Vol. 11 No. 3, pp. 318-334.

PwC India. (2019). Global Entertainment and Media Outlook 2019-2023. Retrieved February 3, 2020, from https://www.pwc.in/pressreleases/2019/global-entertainmentand-mediaoutlook-2019-2023.html.

Ramírez-Correa, P., Rondán-Cataluña, F. J., Arenas-Gaitán, J., and Martín-Velicia, F. (2019), "Analysing the acceptation of online games in mobile devices: An application of UTAUT2", Journal of Retailing and Consumer Services, Vol. 50, pp. 85-93.

Rasoolimanesh, S. M., Md Noor, S., Schuberth, F., and Jaafar, M. (2019), "Investigating the effects of tourist engagement on satisfaction and loyalty", The Service Industries Journal, Vol. 39 No. 7-8, pp. 559-574.

Ringle, C. M., Wende, S., and Becker, J. M. (2015), "SmartPLS 3", wWw.smartpls.com
Sarstedt, M., Ringle, C. M., Cheah, J. H., Ting, H., Moisescu, O. I., and Radomir, L. (2020). "Structural model robustness checks in PLS-SEM". Tourism Economics, Vol. 26 No. 4, pp. 531-554.

Shaikh, S., and Aggarwal, A. (2020), "Lockdown a blessing in disguise?".

Shaw, N., and Sergueeva, K. (2019), "The nonmonetary benefits of mobile commerce: Extending UTAUT2 with perceived value", International Journal of Information Management, Vol. 45, pp. 4455.

Shiva, A., Narula, S., and Shahi, S. K. (2020) "What drives retail investors' investment decisions? Evidence from no mobile phone phobia (nomophobia) and investor fear of missing out (I-FOMO)". Journal of Content, Community and Communication, 10(6), 2-20.

Shahi, S.K., Shiva, A. and Dia, M. (2020), "Integrated sustainable supply chain management and firm performance in the Indian textile industry", Qualitative Research in Organizations and Management, Vol. ahead-of-print No. ahead-of-

print. https:/ / doi.org/10.1108/QROM03-2020-1904

Shin, J., Park, Y., and Lee, D. (2016), “Strategic management of over-the-top services: Focusing on Korean consumer adoption behaviour", Technological Forecasting and Social Change, Vol. 112, pp. 329-337.

Singh, P. (2019). "New Media as a Change Agent of Indian Television and Cinema: A study of over the top Platforms" Journal of Content, Community and Communication, Vol. 9, pp. 131-137.

Stone, M. (1974), “Cross-validation and multinomial prediction", Biometrika, Vol. 61 No. 3, pp. 509-515

Sujata, J., Sohag, S., Tanu, D., Chintan, D., Shubham, P., and Sumit, G. (2015), "Impact of over the top (OTT) services on telecom service providers", Indian Journal of Science and Technology, Vol. 8 No. S4, pp. $145-160$.

Tabsh, B. K. H. (2012), “An investigation of the adoption by banks and acceptance by bank customers of internet banking in 
the Sultanate of Oman", Doctoral dissertation, Cardiff Metropolitan University.

Tak, P., and Panwar, S. (2017), “Using UTAUT 2 model to predict mobile app-based shopping: evidences from India", Journal of Indian Business Research.

Ulin, J. (2013), "The business of media distribution: Monetizing film, TV and video content in an online world", CRC Press.

Voorhees, C. M., Brady, M. K., Calantone, R., and Ramirez, E. (2016), "Discriminant validity testing in marketing: An analysis, causes for concern, and proposed remedies", Journal of the Academy of Marketing Science, Vol. 44 No.
1 ,

pp.

119-134.

https://doi.org/10.1007/s11747-015-

0455-4

Xia, E. A. C., and Cheng, K. T. G. (2017), “The determinants of purchase intention on counterfeit sportswear", Journal of Applied Structural Equation Modeling, Vol. 1 No. 1, pp. 13-26.

Yuan, S., Ma, W., Kanthawala, S., and Peng, W. (2015), “Keep using my health apps: Discover users' perception of health and fitness apps with the UTAUT2 model", Telemedicine and e-Health, Vol. 21 No. 9, pp. 735-741. 